\title{
Gigitiruan sebagian imidiat untuk memperbaiki estetik gigi anterior yang mengalami kelainan periodontal
}

\author{
Ike Damayanti Habar \\ Bagian Prostodonsia \\ Fakultas Kedokteran Gigi Universitas Hasanuddin
}

\begin{abstract}
The treatment of immediate partial denture has the objective of enhancing the aesthetics of the condition and position of protrusive anterior teeth because of periodontal disorder that would improve the face appearance. This case study was carried out on a 32-year old female patient with protrusive and very mobile anterior teeth that obstruct the lips closure. The diagnosis of patient was dental protrusion in upper and lower mandible along with diastema as the result of rapidly progressive periodontitis. The treatment implemented was the construction of immediate partial denture with extraction of the anterior teeth. After insertion, control was performed at 24 hours, three days and seven days. It appeared that aesthetics, occlusion, articulation, retention and stabilization was very good.
\end{abstract}

Key words: immediate partial denture, rapidly progressive periodontitis, aesthetics.

\begin{abstract}
ABSTRAK
Perawatan dengan menggunakan gigitiruan sebagian imidiat bertujuan untuk memperbaiki estetik dari kondisi dan posisi gigi anterior yang protrusif akibat kelainan periodontal sehingga akan memperbaiki penampilan wajah penderita. Studi kasus dilakukan terhadap penderita perempuan berumur 32 tahun dengan gigi anterior yang protrusif dan goyang derajat tiga sehingga menghalangi penutupan bibir. Diagnosis penderita adalah dental protrusion rahang atas dan bawah yang disertai diastema akibat periodontitis progresif cepat. Perawatan yang dilakukan adalah pembuatan gigi tiruan sebagian imidiat dengan ekstraksi pada gigi anterior rahang atas dan rahang bawah. Setelah insersi dilakukan kontrol 24 jam, tiga hari dan tujuh hari, tampak estetik, oklusi, artikulasi, retensi dan stabilisasi yang sangat baik.
\end{abstract}


Kata kunci : gigitiruan sebagian imidiat, periodontitis progresif cepat, estetik.

Koresponden: Ike Damayanti Habar, Bagian Prostodonsia, Fakultas Kedokteran Gigi

\section{PENDAHULUAN}

Gigitiruan imidiat dapat didefinisikan sebagai gigitiruan yang dibuat atau dikonstruksi terlebih dahulu sebelum gigi alami dicabut dan segera diinsersikan setelah pencabutan gigi tersebut. 1

Gigitiruan imidiat dapat berupa gigitiruan lengkap atau gigitiruan sebagian. Penggantian imidiat untuk gigi anterior merupakan jenis yang paling sering dari gigitiruan imidiat.2 Ada dua macam bentuk gigitiruan imidiat, yaitu gigitiruan imidiat dengan sayap (labial flanged) dan tanpa sayap (open face/socketing). 3

Indikasi perawatan dengan menggunakan gigitiruan imidiat adalah bila penderita mengalami karies yang parah pada gigi anterior atau perubahan warna yang hebat yang disebabkan oleh faktor ekstrinsik atau intrinsik. Gigi yang mengalami kelainan periodontal yang parah ditandai dengan hilangnya perlekatan periodontal dan kerusakan pada tulang alveolus sehingga menyebabkan kegoyangan yang hebat. Kelainan posisi dan susunan gigi anterior seperti protrusi, retrusi, berdesakan, gigitan terbalik atau silang, dapat pula disertai dengan kelainan bentuk rahang.1

Kontraindikasi perawatan dengan menggunakan gigitiruan imidiat adalah bila penderita mengalami abses periapikal atau abses periodontal, penyakit diabetes yang tidak terkontrol, penyakit haemofilia, terdapat riwayat penyakit rematik dengan kerusakan jantung, telah menjalani terapi radiasi, terdapat kista atau gigi yang impaksi, riwayat pencabutan gigi yang sukar, kesehatan mulut yang buruk serta tidak kooperatif. 1

Adapun keuntungan utama dari penggunaan gigitiruan imidiat adalah penderita terhindar dari rasa tidak nyaman dan khawatir bila terlihat tidak bergigi atau ompong karena dapat segera memakai gigitiruan. Perawatan ini memungkinkan penderita untuk tetap melakukan kegiatan sosial ataupun bisnis.4,5 Keuntungan lain adalah gigitiruan ini bertindak sebagai bandage, splint untuk mengontrol perdarahan, melindungi luka dari trauma karena lidah, makanan atau gigi antagonis, mencegah cairan mulut dan partikel makanan masuk ke dalam soket gigi serta 
melindungi bekuan darah sehingga mempercepat proses penyembuhan. 6

Kekurangan dari perawatan ini adalah susunan gigi dan estetik tidak dapat diperiksa sebelum proses akrilik dan insersi gigitiruan sehingga diperlukan perencanaan yang lebih cermat.7,8 Biaya perawatan dengan menggunakan gigitiruan imidiat yang lebih mahal daripada pembuatan gigitiruan yang konvensional karena memerlukan relining atau pembuatan gigitiruan yang baru. Selain itu, diperlukan kerjasama dan waktu perawatan yang lebih lama antara dokter gigi, pasien dan laboratorium dental.7

Ketidakteraturan letak gigi yang parah atau protrusi yang berat pada gigi anterior dapat memberikan efek psikologis yang tidak menguntungkan terutama bagi pasien wanita muda. Walaupun perawatan ortodontik dapat dilakukan dan harus selalu dipertimbangkan, tetapi dalam beberapa kasus, pencabutan gigi yang bermasalah lebih dianjurkan. Hal ini terutama bila proklinasi gigi anterior disebabkan oleh kehilangan tulang pendukung. Pada kehilangan tulang akibat penyakit periodontal, tampak gigi migrasi ke arah labial dan terlihat jarak antar gigi.1 Perawatan yang dilakukan adalah dengan pembuatan gigitiruan sebagian imidiat yang bertujuan untuk memperbaiki estetik dari kondisi dan posisi gigi anterior, yang akan memperbaiki estetik wajah dan mengembalikan kepercayaan diri penderita. 9

\section{LAPORAN KASUS}

Seorang penderita perempuan, umur 32 tahun, pekerjaan wiraswasta datang dengan keluhan ingin memperbaiki penampilan gigi-gigi anterior yang tampak protrusif. Gigi anterior atas goyang derajat tiga dan penderita sulit untuk menutup mulutnya. Penderita telah memakai gigitiruan sebagian lepasan pada rahang bawah selama 3 tahun yang dibuat di tukang gigi. Dari pemeriksaan intra oral terdapat gigi hilang pada 41 , gigi goyang derajat tiga dan retraksi gingiva sampai $2 / 3$ akar pada gigi 11, 31, dan 42. Gigi goyang derajat 2 pada gigi 21 dan 32. Gigi microdontia pada gigi 12 dan 22. Telah dilakukan perawatan periodontologi sebelumnya dengan menggunakan splinting selama 6 bulan, tetapi tidak memberikan hasil yang memuaskan. Penderita didiagnosis sebagai dental protrusion rahang atas dan rahang bawah yang disertai diastema 12-11, dan 21-22, oleh karena periodontitis progresif cepat (gambar 1, 2, dan 3). Untuk kasus ini direncanakan perawatan gigitiruan sebagian 
imidiat pada rahang atas dan rahang bawah, dengan basis dan gigi buatan akrilik. Untuk rahang atas, dilakukan ekstraksi imidiat pada gigi 12, 11, 21, dan 22. Klamer half Jackson pada gigi 14, 16, 24, dan 26 dengan perluasan plat pada gigi 13 dan 23 . Sedangkan untuk rahang bawah, dilakukan ekstraksi imidiat pada gigi 42, 31,32. Klamer half Jackson pada gigi 34, 36, 44, dan 46 dengan perluasan plat pada gigi 33 dan 43.

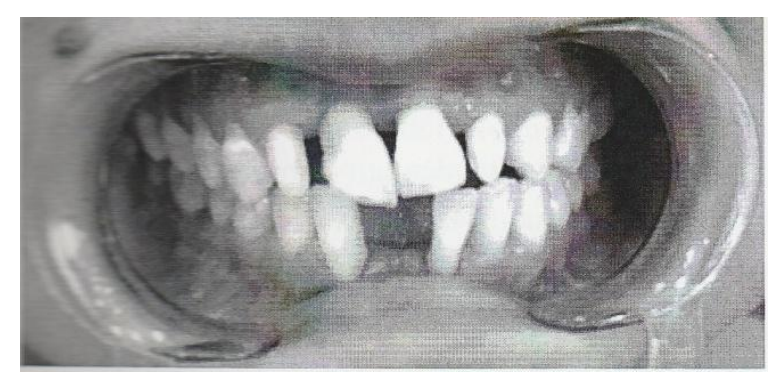

Gambar 1 Tampak depan

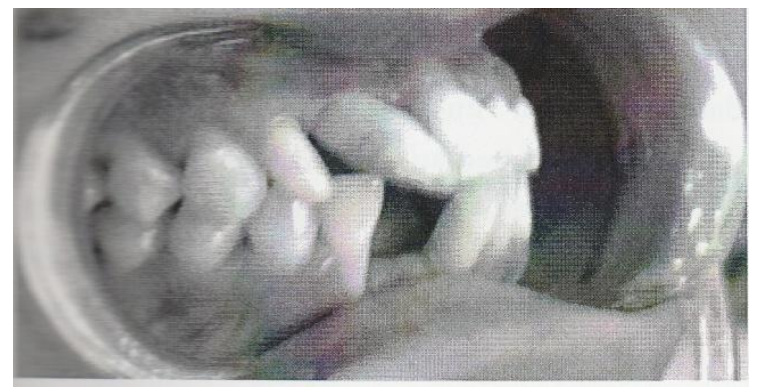

Gambar 2. Tampak samping

Gambar 3. Sebelum perawatan dental protrusion yang disertai

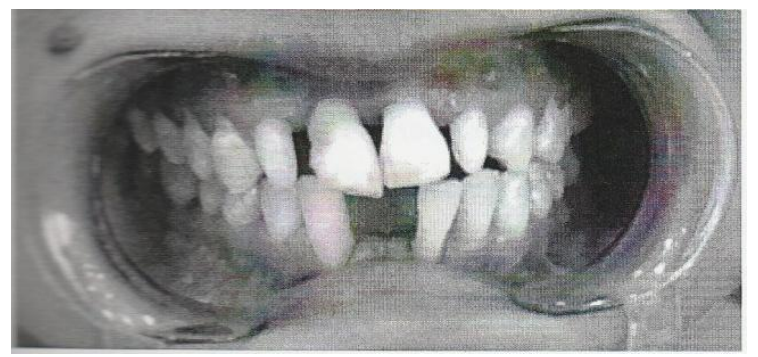

diastema oleh karena periodontis progresif cepat

\section{Prosedur klinik dan laboratorium}

1. Pembuatan foto panoramik dan sefalometri dan model diagnostik.

2. Dilakukan pengasahan untuk lintasan klamer pada gigi 14, 16, 24, 26, 34, 36, 44, dan 46.

3. Mencetak rahang atas dan rahang bawah untuk membuat model kerja, lalu dilanjutkan dengan penetapan gigit dan memasang model kerja pada artikulator.

4. Pengasahan pada model kerja. Bagian servikal mahkota dari gigi yang akan diekstraksi ditandai dengan pensil kemudian diasah dengan hati-hati.

5. Pembuatan klamer half Jackson pada gigi 14, 16, 24, 26, 34, 36, 44 dan 46, dan penyusunan gigi buatan 12, 11, 21, 22, 42, 31 dan 32, dan dilanjutkan dengan proses akrilik.

6. Ekstraksi gigi 42, 31, dan 32 kemudian segera diinsersikan gigitiruan rahang bawah. Selanjutnya dilakukan ekstraksi gigi 12, 11, 21 dan 22, kemudian diinsersikan gigitiruan rahang atas. (Gambar 4, 5)

7. Pada saat insersi, diperhatikan retensi, stabilisasi, oklusi dan estetik. Instruksi 
pada penderita yaitu: gigitiruan tidak boleh dilepas selama 24 jam pertama, makan makanan yang lunak, hindari makan makanan dan minuman yang panas, tidak boleh menggigit pada gigi depan serta kompres dingin bila terjadi perdarahan.

8. Kontrol setelah 24 jam pertama, gigitiruan dilepas dan dicuci. Basis gigitiruan bawah dikurangi karena tampak adanya daerah yang tertekan pada mukosa di sekitar soket gigi 32.

9. Kontrol berikutnya dilakukan 3 dan 7 hari kemudian. Selanjutnya kontrol dilakukan setelah pemakaian 1 bulan, 2 bulan, dan 6 bulan.

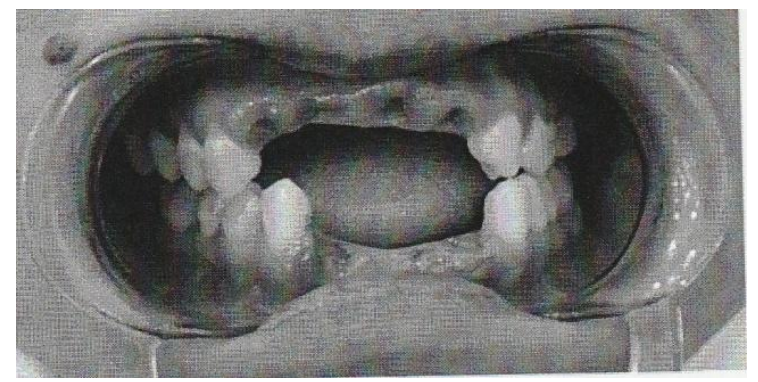

Gambar 4. Pencabutan gigi-gigi 12, 11, 21, 22, 42, 31, dan 32

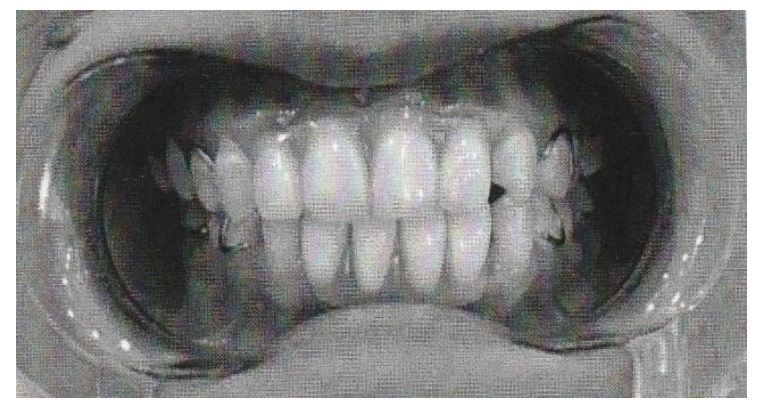

Gambar 5. Insersi gigtiruan 22, 32, 31, dan 42

\section{PEMBAHASAN}

Periodontitis progresif cepat adalah jenis periodontitis yang disertai dengan kehilangan perlekatan dan tulang alveolar yang relatif cepat, yang sering terjadi pada penderita berusia duapuluhan meskipun bisa timbul pada usia mulai puber sampai 30-35 tahun. Berdasarkan ciri-ciri klinisnya, periodontitis progresif cepat dibedakan atas tahap akut dan tahap tenang. Periodontitis progresif cepat tahap akut ditandai dengan inflamasi yang parah disertai perdarahan dan pembesaran gingiva serta eksudasi. Terjadi destruksi tulang alveolar yang berlangsung cepat dalam beberapa minggu atau bulan dan kadang-kadang disertai komplikasi sistemik berupa malaise, kehilangan berat badan dan depresi. Sedangkan pada periodontitis progresif cepat tahap tenang ditandai dengan gingiva terlihat normal dan beradaptasi rapat ke permukaan gigi, kehilangan tulang yang banyak dan saku periodontal yang dalam.10

Pada penderita dengan penyakit periodontal yang berlanjut, perawatan lokal periodontal yang berulang terkadang tidak bermanfaat dan kondisinya secara bertahap akan menjadi lebih buruk dan sulit untuk disembuhkan sehingga sampai pada satu keputusan bahwa tidak ada perawatan konservatif yang dapat menyembuhkan 
kondisi yang parah tersebut dan pada saat itulah perawatan prostodontik dipilih sebagai alternatif terbaik.11

Setelah kehilangan tulang akibat penyakit periodontal, terlihat gigi migrasi ke labial dan jarak antar gigi, sehingga mengakibatkan tampilan yang tidak menyenangkan bagi penderita.1 Pada keadaan demikian, gigi yang "kehilangan harapan" ini harus diekstraksi tanpa ada keraguan dan dilanjutkan dengan perawatan prostodontik. Perawatan ini akan segera memberikan perbaikan fungsi, bentuk dan juga membangun kembali rasa percaya diri penderita.11

Dalam kasus ini dilakukan ekstraksi pada gigi 12,11,21,22,42,31,32 yang sebelumnya didiagnosis sebagai dental protrusion pada rahang atas dan rahang bawah yang disertai diastema yang disebabkan oleh periodontitis progresif cepat.

Setelah ekstraksi dilakukan, kemudian dilanjutkan dengan segera insersi gigitiruan rahang atas dan bawah. Penderita tampak sangat puas dengan gigitiruannya. Terlihat perubahan yang besar pada profil wajahnya, antara lain bibir sudah dapat menutup dengan rapat tanpa adanya kesulitan karena terhalang oleh gigi anterior yang sangat goyang dan protrusif.

Kontrol setelah pemasangan gigitiruan dilakukan dua tahap, yaitu 24 jam dan tujuh hari sesudahnya. Pada kontrol pertama, Gigitiruan dibuka dan dicuci. Adanya tekanan pada jaringan lunak terlihat dari warna mukosa yang nampak lebih pucat bila dibandingkan dengan daerah di sekitarnya yang bebas dari tekanan. Jika ada bagian gigitiruan yang menyebabkan tekanan berlebih, maka dapat langsung dikurangi. Pada kunjungan ini, penderita diajarkan cara memasang dan melepaskan gigitiruannya. Dianjurkan pula untuk berkumur-kumur dengan air garam hangat. 8 Kontrol kedua pada tiga dan tujuh hari setelah operasi, koreksi lanjutan berupa perbaikan terhadap gangguan oklusi dan artikulasi. Selanjutnya kontrol dilakukan sebulan kemudian, lalu secara rutin sekali dalam enam bulan. Bila sudah terlihat adanya resorpsi yang ditandai dengan longgarnya basis, maka diperlukan relining .8

\section{SIMPULAN}

Pemilihan perawatan dengan menggunakan gigitiruan sebagian imidiat untuk memperbaiki estetik gigi anterior yang protrusif akibat kelainan periodontal 
yang parah merupakan alternatif terbaik. Keuntungan utama dari perawatan ini adalah penderita terhindar dari rasa tidak nyaman dan khawatir bila terlihat tidak bergigi atau ompong karena dapat segera memakai gigitiruan. Dengan demikian tujuan penderita untuk mengubah dan memperbaiki kondisi dan posisi gigi anterior yang akhirnya akan memperbaiki estetik wajahnya, dapat segera terwujud.

\section{DAFTAR PUSTAKA}

1. Anderson JN, Storer R. Immediate and replacement dentures. 3rd ed. Oxford: Blackwell Scientific Publications; 1981. p. 20, 31-3, 36, 40-1, 96, 14664.

2. Grant AA, Johnson W. Removable denture prosthodontics. 2nd ed. Edinburgh: Churchill Livingstone; 1992. p. 247-91.

3. Basker RM, Davenport JC, Tomlin HR. Perawatan prostodontik bagi pasien tak bergigi (Prosthetic treatment of the edentuluous patient). Alih bahasa: Soebekti TS, Arsil H. Edisi III. Jakarta: Penerbit Buku Kedokteran EGC; 1996. p. 37-44.

4. Sharry JJ. Complete denture prosthodontics. 3rd ed. New York:
McGraw-Hill Book Company; 1974. p. 295-309.

5. Gottlieb AS, Askinas SW. An atypical chairside immediate denture: A clinical report. J Prosthet Dent 2001; 86 (3): 214-3.

6. Heartwell CM, Rahn AO. Syllabus of complete dentures. 4th ed. Philadelphia: Lea \& Febiger; 1986. p. 441-57.

7. Gunadi HA, Burhan LK, Suryatenggara F, Margo A, Setiabudi I. Buku ajar ilmu geligi tiruan sebagian lepasan. Jilid II. Jakarta: Hipokrates; $1995 . \quad$ p. $367-78$.

8. Soni A. Use of loss fitting copper bands over extremely mobile teeth while making impressions for immediate denture. J Prosthet Dent $1998 ; 81$ (5): 638.

9. Iskandar R. Immediate denture. Majalah Kedokteran Gigi Indonesia. Edisi khusus. 1993. h. 1-5.

10. Daliemunthe SH. Periodonsia klinis. Medan: Universitas Sumatera Utara Press (USU Press); 1995. p. 55-9.

11. Hayawaka I, Osada E, Morisawa M, Nakagawa Y, Watanabe I. Prosthodontic treatment for a patient with advanced hydantoin-associated 
gingival hyperplasia: A case report.

Quintessence Int 1996; 27 (4): 235-41. 